\title{
Strategi Komunikasi Komisi Penanggulangan Aids (KPA) Provinsi Kalimantan Tengah Dalam Menyosialisasikan Penanggulangan HIV Dan AIDS di Kalimantan Tengah
}

An Analysis of Service Quality, Competence and Performance of Pokjar Administrators in Relation to Student Satisfaction at UPBJJ-UT of Palangka Raya

\section{Lisnawati $^{2}$}

Srie Rosmilawati

\author{
*I,2Universitas Muhammadiyah \\ Palangka Raya \\ *email: \\ milakpid@gmail.com
}

\section{Kata Kunci: \\ Strategi Komunikasi \\ Sosialisasi}

HIV \& AIDS

\section{Keywords:}

Communication Strategy

Socialization

HIV \& AIDS

\section{Abstrak}

Permasalahan utama dalam penelitian ini adalah peningkatan jumlah masyarakat di kalimantan tengah yang terinfeksi virus HIV dan AIDS dari tahun ke tahun. Dengan adanya permasalahan tersebut, maka peneliti tertarik untuk mengetahui bagaimana strategi komunikasi Komisi Penanggulangan AIDS (KPA) Provinsi Kalimantan Tengah dalam Menyosialisasikan penananggulangan HIV dan AIDS, dengan lokus penelitian di Provinsi Kalimantan Tengah. Teori yang digunakan dalam penelitian ini adalah Teori Strategi Komunikasi yang Efekttif (Arifin) yaitu penetapan strategi komunikasi didasarkan pada langkah-langkah mengenal khalayak, menyusun pesan, menetapkan metode, dan seleksi media. Penelitian ini menggunakan pendekatan kualitatif dengan teknik pengumpulan data wawancara mendalam, observasi, dan juga dokumentasi. Subjek penelitian yaitu petugas KPA Provinsi Kalimantan Tengah dan juga masyarakat Kalimantan Tengah. Fokus penelitian terletak pada strategi komunikasi yang dilakukan KPA Provinsi Kalimantan Tengah dalam menyosialisasikan Penanggulangan HIV dan AIDS kepada masyarakat. Hasil penelitian menunjukkan bahwa selama ini KPA Provinsi Kalimantan Tengah telah cukup baik dan efektif dalam menyusun strategi komunikasi yang digunakan dalam proses sosialisasi penanggulangan HIVdan AIDS kepada mayarakat Kalimantan Tengah. Hal ini karena indikator penelitian seperti menyusun pesan, menetapkan metode, dan seleksi media telah dilakukan dengan baik dan menimbulkan pengetahuan yang posistif di masyarakat. Sedangkan untuk indikator mengenal khalayak masih kurang efektif karena KPA Provinsi Kalteng tidak melakukan pengenalan khalayak sendiri, dan hanya berpacu pada program pemerintah.

\section{Abstract}

The main problem in this study is the increase in the number of people in Central Kalimantan who are infected with the HIV and AIDS virus from year to year. Given these problems, the researchers were interested to find out how the communication strategy of the Central Kalimantan AIDS Control Commission (KPA) in Socializing HIV and AIDS prevention, with a research locus in Central Kalimantan Province. The theory used in this study is the Theory of Effective Communication Strategies (Arifin), namely the determination of communication strategies based on steps to get to know the audience, compose messages, set methods, and media selection. This study uses a qualitative approach with in-depth interview data collection techniques, observation, and also documentation. The research subjects were KPA officers in Central Kalimantan Province and also the people of Central Kalimantan. The focus of the research lies in the communication strategy undertaken by the KPA of Central Kalimantan Province in socializing HIV and AIDS prevention to the community. The results of the study showed that up to now the KPA of Central Kalimantan Province had been quite good and effective in developing a communication strategy used in the process of socializing HIV and AIDS prevention to the people of Central Kalimantan. This is because research indicators such as composing messages, establishing methods, and media selection have been carried out well and generate positive knowledge in the community. Whereas indicators for getting to know the public are still ineffective because the KPA of Central Kalimantan does not make an introduction to the audience itself, and only refers to government programs. 


\section{Latar Belakang}

Dalam aktivitas penanggulangan HIV/ AIDS, strategi komunikasi menjadi salah satu aspek penting bagi KPA Propinsi Kalimantan Tengah sebagai penentu keberhasilan program penangulangan epidemi HIVIAIDS di Provinsi Kalimantan Tengah. Strategi komunikasi yang dilakukan oleh KPA Provinsi Kalimantan Tengah, selama ini dinilai belum memberikan pengaruh pada pembentukan atau perubahan paradigma di kalangan kelompok sasaran mengenai bahaya HIVIAIDS. Hal tersebut dapat diketahui dari angka penderita HIVIAIDS di Provinsi Kalimantan tengah. Berdasarkan pada laporan dari tahun ke tahun, di Provinsi Kalimantan Tengah sampai bulan Juni 2018, jumlah kasus penderita HIVIAIDS ialah sebanyak III7 kasus. Dari jumlah kasus tersebut terdiri dari penderita HIV sebanyak 735 orang, dan yang telah berlanjut ke AIDS serta yang telah meninggal dunia sebanyak 382 orang.

$$
\text { Beberapa permasalahan }
$$

terkait penanggulangan HIVIAIDS di Provinsi Kalimantan Tengah salah satunya KPA belum memiliki model atau strategi komunikasi yang efektif. Strategi komunikasi yang efektif artinya penyebaran informasi tentang penanggulangan HIVIAIDS yang disampaikan akurat, menyeluruh dan tepat sasaran

Mengingat strategi komunikasi memegang peranan penting dalam sosialisasi meningkatkan pengetahuan masyarakat tentang Penanggulangan HIVIAIDS dilakukan KPA Provinsi Kalimantan Tengah, maka dari itu peneliti ingin meneliti mengenai Bagaimana "Strategi Komunikasi Komisi Penanggulangan AIDS (KPA) Provinsi Kalimantan Tengah dalam Mensosialisasikan Penanggulangan HIVIAIDS di Provinsi Kalimantan Tengah".

\section{A. Perumusan Masalah}

Berdasarkan uraian latar belakang masalah diatas, maka dapat disimpulkan perumusan masalah sebagai berikut:

"Bagaimana strategi komunikasi Komisi Penanggulangan AIDS (KPA) Provinsi Kalimantan Tengah dalam Mensosialisasikan Penganggulangan HIVIAIDS di Provinsi Kalimantan Tengah?”

\section{B. Tujuan}

Tujuan umum penelitian ini yaitu untuk mengetahui strategi komunikasi Komisi Penanggulangan AIDS (KPA) Provinsi Kalimantan Tengah dalam Mensosialisasikan Penganggulangan HIVIAIDS di Provinsi Kalimantan Tengah

\section{Manfaat}

Penelitian ini diharapkan dapat memberikan manfaat bagi pengembangan ilmu sebagai bahan pengetahuan terutama dalam bidang komunikasi, serta agar dapat berguna bagi lembaga yang bersangkutan dalam mengembangkan strategi komunikasi yang efektif dalam mensosialisasikan penanggulangan HIVIAIDS di Provinsi Kalimantan Tengah

\section{Ruang Lingkup Penelitian}

Penelitian ini bermaksud untuk mengetahui strategi komunikasi yang digunakan oleh KPA Provinsi Kalimantan Tengah yang selama ini dianggap masih kurang efektif dalam mensosialisasikan pesan mengenai penanggulangan HIV/AIDS di Provinsi Kalimantan Tengah. Tedapat beberapa indikator yang digunakan dalam mengetahui strategi komunikasi dalam penelitian ini yaitu mengenal khalayak, menyusun pesan, menetapkan metode dan juga seleksi media.

\section{BAB II}

\section{TINJAUAN PUSTAKAN DAN KERANGKA KONSEP}

\section{A. Tinjauan Pustaka \\ I. Strategi Komunikasi}

Strategi adalah rencana manajemen instansi atau organisasi dalam jangka panjang dari hal yang umum menuju hal yang khususuntuk mencapai tujuan yang telah disusun sebelumnya serta akan dijadikan acuan dalam segala kegiatan instansi. Dengan adanya strategi ini maka sebuah instansi akan lebih mudah dalam melaksanakan setiap kegiatannya.

Sedangkan komunikasi berasal dari bahasa latin "Communis" yang artinya membuat kebersamaan atau membangun kebersamaan antara dua orang atau lebih. Komunikasi juga berasal dari akar kata dalam bahasa Latin "Communico" yang artinya membagi. (Cangara,20I3:20) Menurut Harold D Lasswell (Cangara, 20I3), komunikasi adalah siapa yang berkata apa, melalui saluran apa, kepada siapa, dan apa efek yang ditimbulkan (who, says, what, through what channel, to whom, and what effect). Model ini banyak dikenal sebagai Formula Laswel yang merupakan model komunikasi yang dipengaruhi oleh model dasar.

Menurut Onong Uchjana Effendi dalam buku berjudul "Dinamika Komunikasi" menyatakan bahwa:

“...Strategi komunikasi merupakan panduan dari perencanaan komunikasi (communication planning) dan manajemen untuk mencapai suatu tujuan. Untuk mencapai tujuan tersebut strategi komunikasi harus menunjukkan secara taktis bagaimana operasionalnya. Dalam arti kata bahwa pendekatan (approach) bisa berbeda sewaktu-waktu bergantung kepada situasi dan kondisi... Effendy, (2013).

Penetapan strategi komunikasi didasarkan pada langkah-langkah mengenal khalayak, menyusun pesan, menetapkan metode, seleksi 
dan penggunaan media Arifin, (1984), sebagai berikut:

a. Mengenal khalayak

Memahami target sasaran kegiatan komunikasi, merupakan hal yang sangat penting sebab semua aktivitas komunikasi diarahkan kepada mereka. Merekalah yang menentukan berhasil tidaknya suatu program.

b. Menyusun pesan

Syarat utama dalam mempengaruhi khalayak dari pesan tersebut ialah mampu menarik perhatian khalayak.Menurut suryanto (2015: 177) pesan yang disampaikan akan tepat dan mengenai sasaran, memenuhi syarat-syarat sebagai berikut:

a. Pesan harus direncanakan dengan baik (disiapkan) serta sesuai dengan kebutuhan.

b. Pesan menggunakan bahasa yang dapat dimengertioleh kedua belah pihak.

c. Pesan itu harus menarik minat dan kebutuhan pribadi penerima serta menimbulkan kepuasan

c. Menetapkan Metode

Untuk mencapai efektivitas komunikasi maka tidak hanya bergantung pada kemantapan isi pesan yang diselaraskan dengan kondisi khalayak, namun juga dipengaruhi oleh metode-metode dalam menyampaikan pesan kepada sasaran.

Menurut cara pelaksanaannya, metode komunikasi diwujudkan dalam bentuk :metode redudancy, dan metode canalizing. Sedangkan menurut bentuk isinya, metode komunikasi diwujudkan dalam bentuknya yaitu metode informatif, metode edukatif, metode koersif, dan metode persuasif.

d. Seleksi dan penggunaan media

Menurut Suryanto (2015:187-188) media komunikasi memiliki beberapa fungsi yaitu efektifitas yaitu mempermudah kelancaran penyampaian informasi. efisiesi yaitu mempercepat penyampaian informasi, konkret yaitu membantu mempercepat isi pesan yang bersifat abstrak, dan motivatif yaitu menambah semangat untuk melakukan komunikasi

\section{Sosialisasi}

Sosialisasi merupakan salah satu fungsi komunikasi yang berperan penting dalam pola tingkah laku seseorang ditengah-tengah masyarakat dan lingkungannya. Sosialisasi dapat diartikan sebagai proses yang membantu individu melalui belajar dan menyesuaikan diri, bagaimana cara hidup dan berpikir dalam suatu kelompok masyarakat.
MacBride dalam Effendy mengemukakan bahwa sosialisasi adalah penyediaan sumber ilmu pengetahuan yang memungkinkan orang bersikap dan bertindak sebagai anggota masyarakat yang efektif yang menyebabkan ia sadar akan fungsi sosialnya sehingga ia dapat aktif di dalam masyarakat.

\section{HIVIAIDS}

Virus Imunodifisiensi Manusia atau dalam Bahasa Inggris disebut Human Immunodeficiency Virus; HIV ) adalah suatu virus yang dapat menyebabkan penyakit AIDS. Virus ini menyerang manusia dan menyerang sistem kekebalan (imunitas) tubuh, sehingga tubuh menjadi lemah dalam melawan infeksi. Tanpa pengobatan, seorang dengan HIV bisa bertahan hidup selama 9-II tahun setelah terinfeksi, tergantung tipenya(Jenny Page, Maylani Louw, Delene Pakkiri, Monica Jacobs, 2006). Sedangkan AIDS (Acquired Immunodeficiency Sindrom/ Sindrom Imunodefisiensi) adalah stadium akhir pada serangkaian abnormalitas imunologis dan klinis yang dikenal sebagai spectrum HIV (Price, Wilson 1992).

HIV dapat ditularkan melalui injeksi langsung ke aliran darah, serta kontak membran mukosa atau jaringan yang terlukan dengan cairan tubuh tertentu yang berasal dari penderita HIV (Hung Fan, Ross F. Conner, Luis P. Villarreal. 2010). Cairan tertentu itu meliputi darah, semen, sekresi vagina, dan ASI. Menurut Beberapa jalur penularan HIV yang telah diketahui adalah melalui hubungan seksual, dari ibu ke anak (perinatal), penggunaan obat-obatan intravena, transfusi dan transplantasi, serta paparan pekerjaan.

\section{BAB III METODE PENELITIAN \\ A. Pendekatan Penelitian}

Penelitian yang berjudul "Strategi Komunikasi Komisi Penanggulangan AIDS (KPA) Provinsi Kalimantan Tengah dalam Mensosialisasikan Penanggulangaan HIVIAIDS di Provinsi Kalimantan Tengah" ini menggunakan pendekatan penelitian kualitatif. Pendekatan penelitian kualitatif ini bertujuan untuk menjelaskan fenomena sedalam-dalamnya.

\section{B. Tempat dan Waktu Penelitian}

Penelitian ini akan dilaksanakan di Kantor Komisi Penanggulangan AIDS (KPA) Provinsi Kalimantan Tengah.

Waktu penelitian merupakan waktu dimana penelitian ini dilakukan mulai dari penyusunan proposal hingga selesai penulisan penelitian. Proses penyelesaian penelitian ini di mulai dari bulan april dan selesai pada bulan desember. 


\section{Sumber Data}

Menurut Moleong (2010: 14) bahwa sumber data utama dalam penelitian kualitatif ialah kata-kata dan tindakan selebihnya adalah data tambahan seperti dokumen dan lain-lain. Dimana data hasil penelitian didapatkan melalui dua sumber data,yaitu:

\section{DataPrimer}

Data primer adalah data yang diperoleh langsung dari hasil wawancara yang diperoleh dari narasumber atau informan yang dianggap berpotensi dalam memberikan informasi yang relevan dan sebenarnya di lapangan.

\section{DataSekunder}

Data sekunder adalah sebagai data pendukung data primer dari literatur dan dokumen serta data yang diambil dari proses sosialisasi di Komisi Penanggulangan AIDS (KPA) Provinsi Kalimantan Tengah dengan permasalahan dilapangan yang terdapat pada lokasi penelitian berupa bahan bacaan, bahan pustaka,dan laporanlaporan penelitian.

\section{Metode Pengambilan Sampel}

Teknik penentuan informan dalam penelitian ini adalah purposive sampling dengan kriteria informan adalah orang-orang yang bener-benar mengetahui dan terlibat langsung dalam pembentukan strategi komunikasi dalam upaya mensosialisasikan HIVIAIDS yang dilakukan oleh Komisi Penanggulangan AIDS (KPA) Provinsi Kalimantan Tengah sehingga peneliti dapat mengambil dan mengolah informasi yang tepat dan dapat dipercaya.

\section{E. Metode Pengumpulan Data}

Metode pengumpulan data adalah teknik atau cara-cara yang dapat digunakan peneliti untuk mengumpulkan data-data yang diperlukan dalam penelitian. Teknik pengumpulan data yang digunakan dalam penelitian ini, antara lain yaitu observasi, wawancara Mendalam (Depth Interview), dan dokumentasi

\section{F. Fokus Penelitian}

Adapun fokus pada penelitian ini adalah strategi komunikasi yang dilakukan oleh Komisi Penanggulangan AIDS (KPA) Provinsi Kalimantan Tengah dalam mensosialisasikan HIVIAIDS dikalangan masyarakat kota Palangka Raya. Strategi komunikasi yang dimaksudkan dalam penelitian ini didasarkan pada beberapa indikator beberapa indikator antara lain: (I) mengenal khalayak, (2) menyusun pesan, (3) menentukan metode, dan juga (4) seleksi media.

\section{G. Analisis Data}

Teknik analisa data dalam penelitian ini yaitu menggunakan analisis model yang dipopulerkan oleh Miles dan Huberman diantaranya adalah :

I. Pengumpulan Data

2. Reduksi Data

3. Penyajian Data

4. Penarikan Kesimpulan

\section{BAB IV}

\section{HASIL PENELITIAN}

Suatu pesan yang akan disosialisasikan dapat diterima dan dipahami dengan baik oleh khalayak maka pesan tersebut harus dikemas dengan penyampaian yang menarik. Untuk membuat penyampaian pesan agar menarik ini dibutuhkan suatu srategi komunikasi agar tujuan akhir sosialisasi itu senditri dapat tercapai.

Menurut Onong Uchjana Effendi dalam buku berjudul "Dinamika Komunikasi" menyatakan bahwa:

“...Strategi komunikasi merupakan panduan dari perencanaan komunikasi (communication planning) dan manajemen untuk mencapai suatu tujuan. Untuk mencapai tujuan tersebut strategi komunikasi harus menunjukkan secara taktis bagaimana operasionalnya. Dalam arti kata bahwa pendekatan (approach) bisa berbeda sewaktu-waktu bergantung kepada situasi dan kondisi... Effendy, (2013).

Dalam pengertian strategi komunikasi yang diungkapkan oleh Onong Uchjana Effendi ini dapat diketahui bahwa strategi komunikasi memberikan cara-cara yang lengkap dalam suatu pelaksanaan komunikasi yang akan dilakukan. Selama ini, sebelum melakukan suatu program sosialisasi, Komisi Penanggulangan Aids Provinsi Kalimantan Tengah (KPAP Kalteng) selalumelakukan perencanaan agar tujuan sosialisasinya tercapai.

Dari tahun ke tahun, kasus hiv dan aids di kalimantan tengah selalu mengalami peningkatan.hal ini yang melatarbelakangi KPAP Kalteng untuk turun langsung melakukan sosialisasi di tengah masyarakat dengan memberikan edukasi terkait penanggulangan hiv atau aids mulai dari pencegahan, pemeriksaan, hingga pengobatan. Untuk itulah strategi komunikasi pada proses sosialisasi penanggulangan hiv dan aids memerlukan adanya pelaksanaan dari indikator strategi komunikasi yang efektif seperti yang dikemukakan oleh Arifin, (1984), diantaranya adalah mengenal khalayak, menyusun pesan, menetapkan metode, seleksi dan penggunaan media.

I. Mengenal khalayak

Dalam proses komiunikasi mengenal khalayak adalah langkah penting karena baik 
komunikator maupun komunikan mempunyai kepentingan yang sama. Penganalan khalayak ini bisa dilatarbelakangi oleh beberapa faktor seperti jenis pekerjaan, umur, dan pendidikan. Pengenalah khalayak yang baik yaitu dengan perencanaan khusus dengan mempertimbangkan hal-hal yang dianggap penting. Kesamaan kepentingan dalam berkomunikasi yang membuat komunikasi dapat terjalin secara dua pihak. Dalam menyamakan kepentingan maka komunikator perlu menyusun strategi dalam menentukan khalayak yang tepat untuk dilakukan sosialisasi. Penentuan khalayak ini dapat meliputi :

a. Kondisi kepribadian dan fisik komunikan

b. Pengaruh kelompok dan masyarakat serta nilai nilai norma yang ada

c. Situasi dimana komunikan itu berada

Dalam hal pengenalan khalayak ini KPA Kalimantan Tengah lebih terpacu kepada sasaran yang telah ditentukan sebelumnya oleh pemerintah. Pemerintah selama ini lebih menekankan orang dengan resiko tinggi sebagai khalayak yang akan menerima pesan-pesan sosialisasi dari KPA Kalteng. Hal ini dikarenakan orang dengan resiko tinggi memiliki pekerjaan atau aktifitas yang berhubungan langsung terhadap faktor-faktor penularan virus HIVdan AIDS. Sedangkan dalam pengenalayan khalayak juga dapat dilihat dari kasuskasus yang ada di masyarakat. Jika dilihat dari kasus pada tahun 2018, orang dengan pekerjaan sebagai karyawan dan tenaga profesional yang menjadi angka tertinggi orang dengan hiv/aids. Namun dengan hanya berpacu pada program pemerintah maka KPA Kalteng kurang leluasa dalam menentukan khalayak atau komunikan dalam sosialisasi penanggulangan HIVdan AIDS. Padahal seharusnya pihak KPA Kalteng lah yang lebih mengetahui lebih jelas target sasaran komunikan yang tepat untuk menerima pesan terkait penanggulangan HIVdan AIDS tersebut, karena KPA Kalteng yang memiliki tanggung jawab untuk menyamakan kepentingan dengan khalayak sehingga pesan sosialisasi dapat berjalan secara efektif.

\section{Menyusun Pesan}

Dalam satu waktu, terkadang individu dipengaruhi oleh banyak pesan dari berbagai sumber. Tetapi tidak semua pesan dapat diterima dengan baik oleh komunikan. Untuk dapat mempengaruhi komunikan maka komunikator harus mampu membangkitkan perhatian komunikan agar komunikan lebih terpusat pada pesan yang disampaikan komunikator tersebut. Menurut suryanto (2015: 177) pesan yang disampaikan akan tepat dan mengenai sasaran, memenuhi syarat-syarat sebagai berikut:

d. Pesan harus direncanakandengan baik (disiapkan) serta sesuai dengan kebutuhan. e. Pesan menggunakan bahasa yang dapat dimengertioleh kedua belah pihak.

f. Pesan itu harus menarik minat dan kebutuhan pribadi penerima serta menimbulkan kepuasan

Selama ini KPA Kalteng selalu memperhatikan pesan yang akan disampaikan kepada khalayak. Sebelum melakukan sosialisai, KPA Kalteng terleih dahulu menentukan temadan materi yang tepat disesuaikan dengan target audien ataukomunikan yang akan menerima pesan sosialisasinya. Pesan sosialisasi yang dilakukan KPA Kalteng meliputi pencegahan, pemeriksaan, hingga pengobatan. Setiap sosialisasinya, KPA Kalteng sebenarnya menyampaikan hal yang sama terkait tiga hal tersebut namun pesan itu dikemas dengan tema yang menyesuaikan dengan umur atau pekerjaan audiens. Penyesuaian tema ini berguna agar komunikan atau khalayak lebih tertarik dan lebih dapat mencerna pesan yang di sampaikan. Sehingga dapat disimpulkan bahwa KPA Kalteng sudah cukup baik dalam melakukan penyusunan pesan sosialisasinya.

\section{Menetapkan Metode}

Dalam dunia komunikasi metode penyampai pesan dapat dilihat dari dua aspek yaitu menurut cara pelaksanaannya dan menurut bentuk isinya. Metode yang dilihat dari cara pelaksanaannya yaitu metode redundansy (repetition atau diulang-ulang) dan canalizing (mendalam). Sedangkan jika dilihat dari bentuk isinya maka metodenya seperti informatif, persuasif, edukatif, dan kursif. Menetapkan metode ini juga sangat penting dalam strategi komunikasi. Karena dengan menentukan metode yang tepat sasaran maka pesan pun dapat mudah dipahami oleh masyarakat.

Berbagai macam metode telah dilakukan KPA Kalteng dalam melakukan program sosialisasi penanggulangan HIV dan Aids di wilayah Kalimantan Tengah seperti turun langsung ke masyarakat dan melakukan orasi di acara publik, melakukan FGD, dan beberapa metode lainnya. Metode-metode yang dilakukan KPA Kalteng ini lebih ditekankan pada bentuk isinya yang informatif, edukatif, dan persuasif. KPA Kalteng berusaha untuk mengedukasi ke masyarakat dengan menginformasikan hal-hal terkait HIV dan AIDS, serta mengajak masyarakatt untuk melakukan pemeriksaan agar masyarakat mengetahui terlebih dahulua pakah dirinya tertular hiv atau tidak.

Metode yang disusun oleh KPA ini tentu menyesuaikan dengan tempat dilakukannya sosialisasi dan sasaran atau audiens yang hadir dalam sosialisasi. KPA Kalteng pun terus melakukan sosialisasi dengan metode-metode yang dianggap lebih mudah di pahami oleh masyarakat 
agar angka penularan HIV dan AIDS semakin menurun.

\section{Seleksi Media}

Saluran komunikasi atau media adalah perantara dalam penyampaian informasi dari komunikator kepada komunikan yang bertujuan untuk efisiensi penyebaran informasi atau pesan tersebut. Menurut Suryanto (2015:187-188) media komunikasi memiliki beberapa fungsi yaitu :

a. Efektifitas yaitu mempermudah kelancaran penyampaian informasi.

b. Efisiesi yaitu mempercepat penyampaian informasi

c. Konkret yaitu membantu mempercepat isi pesan yang bersifat abstrak

d. Motivatif yaitu menambah semangat untuk melakukan komunikasi

Media komunikasi sangat berperan penting dalam program sosialisasi yang dilakukan KPA Kalteng. Selama ini KPA Kalteng cukup mengandalkan media sosial seperti Facebook, WhatsApp dan juga Instagram untuk menyampaikan pesan-pesan penanggulangan HIV dan AIDS. Selain itu KPA Kalteng juga menggunakan media cetak dan media elektronik untuk press realeas mengenai program-program sosialisasi yang telah mereka lakukan. Walaupun untuk media cetak dan elektronik harus di sesuaikan dengan anggaran yang ada

Media komunikasi yang digunakan KPA Kalteng ini bertujuan untuk membuka komunikasi dengan masyarakat agar masyarakat dapat terbiasa mendengar hal tentang HIV dan AIDS karena selama ini masyarakat Kalimantan Tengah masih tertutup atau enggan untuk membicarakan HIV atau AIDS itu sendiri. Dengan media ini juga KPA Kalteng mengajak serta menuntu masyarakat yang ingin melakukan pemeriksaan HIVdan AIDS. Dengan pemanfaatan media yang cukup baik ini membuat masyarakat Kalimantan Tengah dapat lebih mudah mengetahui bagaimana mencegah terjadinya penularan HIV dan AIDS sehingga tujuan sosialisasi dapat lebih mudah tercapai.

5. Tingkat Pengetahuan di Masyarakat

Rogers dalam Cangara (2013: 6I)

memberi batasan pengertian strategi komunikasi sebagai suatu rancangan yang dibuat untuk mengubah tingkah laku manusia dalam skala lebih besar melalui transfer ide-ide baru. Strategi komunkasi memungkinkan suatu tindakan komunikasi dilakukan untuk target-target komunikasi yang dirancang sebagai target perubahan.

Adapun syarat sebagai faktor penyebab keberhasilan komunikasi yang patut diperhatiakan ialah kerangka pengeratahuan dan lingkup pengalaman. Hal tersebut penting karena jika seorang komunikan tidak cukup memiliki pengetahuan dan pengalaman, maka komunikator harus lebih pandai untuk bisa membuat pesan itu sampai dan dimengerti oleh komunikan.

Sementara itu, menurut R. Wayne Pace, Brent D. Peterson, dan M. Dallas Burnett menyatakan bahwa strategi komunikasi memiliki 3 (tiga) tujuan, yaitu (Effendy, 1984 : 35-36) :

I. To secure understanding - memastikan pesan diterima oleh komunikan.

2. To establish acceptance - membina penerimaan pesan.

3. To motivate action - kegiatan yang dimotivasikan

Berdasarkan hasil dari sosialisasi yang dilakukan KPA Kalteng telah menunjukkan hal yang positif. Dengan berbagai strategi yang telah disusun oleh KPA Kalteng, masyarakat menjadi lebih paham mengenai bagaimana cara menanggulangi HIV dan AIDS. Bahkan untuk saat ini sudah banyak masyarakat yang termotivasi untuk melakukan pemeriksaan guna mengetahui apakah dirinya tertular HIV dan AIDS atau tidak.

Sehingga dari tiga tujuan strategi komunikasi yang diungkapkan oleh R. Wayne Pace, Brent D. Peterson, dan M. Dallas Burnett tersebut telah cukup berhasil diwujudkan oleh KPA Kalteng dalam sosialisasinya. Masyarakat yang sebelumnya tidak mengenal Komisi Penanggulangan Aids akhirnya mengetahui program dari komisi ini sendiri. Selain itu dengan adanya sosialisasi ini masyarakat kalteng jadi mulai sadar untuk lebih menjaga pergaulan dan melakukan pola hidup yang lebih sehat demi terhindar dari virus HIV dan AIDS.

\section{BAB III PENUTUP}

\section{A. KESIMPULAN}

Dari hasil penelitian yang telah dilakukan peneliti di Komisi Penanggulangan Aids (KPA) Provinsi Kalimantan Tengah, peneliti menyimpulkan bahwa strategi komunikasi dalam sosialisasi penanggulangan HIV dan AIDA yang di lakukan oleh Komisi Penanggulangan Aids (KPA) Provinsi Kalimantan Tengah dianggap sudah cukup efektif karena indikator strategi komunikasi yang efektif seperti mengenal khalayak, menyusun pesan, menetapkan metode, dan seleksi media telah dilakukan dengan baik dan menimbulkan pengetahuan yang posistif di masyarakat.

Dari kelima indikator tersebut, hanya ada satu indikator yang dianggap masih cukup lemah pada proses strategi komunikasi dalam sosialisasi penanggulangan HIV dan AIDS yang di lakukan oleh Komisi Penanggulangan Aids (KPA) Provinsi 
Kalimantan Tengahyaitu menetapkan khalayak. Penyebab lemahnya indikator tersebut karena KPAP tidak secara langsung menetapkan khalayak namun hanya mengikuti target yang ditetapkan pemerintah.

Sedangkan indikator lainnya seperti menyusun pesan, meneapkan metode dan juga seleksi media dianggap sudah cukup efektif. Pesan sosialisasi HIV dan AIDS yang disampaikan oleh KPA Provinsi Kalimantan Tengah yang disampaikan dengan berbagai metode yang dianggap cukup baik membuat masyarakat lebih mudah memahami pesan yang disampaikan. Selain itu dengan pemanfaatan media yang efektif maka masyarakat bisa lebih mudah mendapatkan informasi yang disampaikan oleh KPA Provinsi Kalteng. Dengan berhasilnya program sosialisasi yang dilakukan KPA Provinsi Kalteng ini maka akan membuat tingkat pengetahuan masyarakat tentang HIV dan AIDS pun semakin meningkat dan kemungkinan dapat menurunkan angka penularan HIV dan AIDS.

\section{B. SARAN}

Berdasarkan pada kesimpulan di atas, terdapat saran untuk Komisi Penanggulangan HIV dan AIDS (KPA) Provinsi Kalteng yaitu hendaknya Komisi Penanggulangan HIV dan AIDS (KPA) Provinsi Kalteng lebih kreatif dan inovatif dalam mengenal khalayak yang akan dijadikan sebagai komunikan pada program sosialisasi penanggulangan HIV dan AIDS. Selain itu diharapkan KPA Provinsi Kalteng juga harus memperluas kerjasama dengan berbagai stakeholder diluar dari program pemerintah.

\section{DAFTAR PUSTAKA}

Arifin, Anwar. 1984. Strategi Komunikasi: Sebuah Pengantar Ringkas. Bandung:Armico.

Cangara, Hafied. 20I3. Pengantar Ilmu Komunikasi. Jakarta. Rajawali Pers.

Effendy, Onong Uchjana. 20I3. Ilmu, Teori \& Filsafat Komunikasi. Bandung: Citra Aditya Bakti.
Felissa R.Lashley, Jerry D. Durham. 2009. The Person with HIVIAIDS: nursing Perspectives. Spinger Publishing Company.

Hung Fan, Ross F. Conner, Luis P. Villarreal. 2010. AIDS: Science and Society. Jones \& Bartlett Publishers.

Jenny Page, Maylani Louw, Delene Pakkiri, Monica Jacobs, 2006. HIVIAIDS. Cape Town: Juts Legal and Academic Publishers.

Kriyantono, Rachmat. 2012. Teknik Praktis Riset Komunikasi: Disertai Contoh Praktis Riset Media, Public Relation,Advertising, Komunikasi Organisasi, Komunikasi Pemasaran. Jakarta. Kencana Prenada Media Group.

Kementrian Kesehatan RI, Petunjuk Teknis Program Pengendalian HIVI AIDS dan PIMS Fasilitas Kesehatan Tingkat Pertama. Direktorat Jenderal Pencegahan dan Pengendalian Penyakit. 2016.

LiteploR, Gomes Ms R. Fluorides. World Health Organization. 2002.

Moleong, M.A. 20I0. Metodologi Penelitian Kualitatif. Bandung. PT. Remaja Rosdakarya.

Price, S.A., Wilson,L.M. 1992. Patofisioligi, Konsep Klinis Proses-Proses Penyakit. Jakarta: Penerbit Buku Kedokteran, EGC.

Rakhmat. Jalaludin, 200I. Psikologi Komunikasi, Remaja Rosdakarya . Bandung.

Suryanto. 20I5. Pengantar IImu Komunikasi. Bandung: CV Pustaka

Umar, husein, 2002. Metode Riset komunikasi Organisasi, PT Gramedia Pustaka Utama. Jakarta. 